J urra PenddkanBdesadenSastra, V dume12, Nomr 1, April 2012

\title{
SPIRITUALISASI PENDIDIKAN DALAM KARYA SASTRA: SUATU PERSPE KTIF SASTRA BANDINGAN
}

\author{
Yulia Fitrina \\ Balai Bahasa Padang \\ Korespondensi: Jln. Pauh Lima Simpang Alai Kampung D alam, Padang 25162 \\ Pos-el: fitrinayulia@ymail.com
}

\begin{abstract}
Abstrak
Spiritualisasi Pendidikan dalam Karya Sastra: Suatu Perspektif Sastra Bandingan. Spiritualisasi pendidikan merupakan konsep dalam dunia pendidikan yang memadukan antara pendidikan dan unsur spiritual. Nilai-nilai spiritual dalam pendidikan ini dapat ditemukan dalam dua karya sastra berbentuk novel, yakni Laskar Pelangi karya Andrea Hirata dan novel Negeri 5 Menara karya Ahmad Fuadi, yang akan di analisis melalui perspektif sastra bandingan. Di dalam tulisan ini akan dideskripsikan nilai-nilai spiritual yang dijadikan basis dalam mencetak generasi unggul dalam dunia pendidikan yang terefleksi dalam kedua novel sehingga mampu menghasilkan lulusan yang mampu bersaing dalam dunia global. Konsep-konsep spiritualisasi pendidikan dalam kedua novel ini akan dilihat dari dua sisi sekaligus yakni pendidik dan juga peserta didik.
\end{abstract}

Kata kunci: spiritualisasi pendidikan, karya sastra, sastra bandingan

\begin{abstract}
Spiritualization of Education in Literary Works: A Comparative Literary Perspective. Spiritualization of education is a concept in the field of education that combines education and spiritual elements. Spiritual values in education can be found in two literary works in the forms of novels, such as the Laskar Pelangi novel by Andrea Hirata and Negeri 5 Menara by Ahmad Fuadi, which will be analyzed through the perspective of comparative literature. This paper will describe the spiritual values that form the basis for the creation of leading generation in the world of education as reflected in both novels so as to produce graduates who can compete in the global world. Concepts of spiritualization of education in both of these novels will be seen from two sides at once, that is, educators and learners.
\end{abstract}

Keywords: spiritualiztion of education, literary works, comparative literary works

p-ISSN 1412-0712 | e-ISSN 2527-8312 